\title{
For a political economy of financialization: theory and evidence *
}

\author{
José Carlos Braga \\ Giuliano Contento de Oliveira ${ }^{* *}$ \\ Paulo José Whitaker Wolf ${ }^{* *}$ \\ Alex Wilhans Antonio Palludeto ** \\ Simone Silva de Deos ${ }^{* *}$
}

\begin{abstract}
The end of the Bretton Woods agreement led not only to changes in the international economic relations, but also in the very way in which capitalism functions. The liberalization of capital flows and deregulation and integration of financial markets under US leadership gave rise to a new systemic pattern of wealth, financialization, in which operations with financial assets received increased importance in the management of wealth by households and enterprises, and not only by banks and the other financial market institutions. Unlike most recent interpretations of this phenomenon, this one does not indicate a tendency of the system towards stagnation, but rather an increase in the instability that characterizes it, reinforcing the moments of expansion, contraction, as well as leading to crises. In fact, with the generalization and the dominance of finance, borrowing and spending decisions by enterprises and households are now increasingly responsible for current and expected fluctuations in the stock of wealth, which in turn are responsive to current and expected fluctuations in the prices of financial assets. This implies a transformation in the relationship between the state and the market, with central banks and national treasures becoming hostage to the need to prevent private losses and the perverse effects they may exercise over output, income and employment levels of the economy.
\end{abstract}

Keywords: Financialization; Contemporary capitalism; Economic dynamic; Instability; Inequality.

\section{Resumo}

\section{Por uma economia política da financeirização: teoria e evidências}

O fim do arranjo de Bretton Woods ensejou não apenas uma mudança na forma de funcionamento das relações econômicas em âmbito mundial, mas também no próprio modo de operação do capitalismo. A liberalização dos fluxos de capitais e a desregulamentação e integração dos mercados financeiros internacionais sob a liderança dos Estados Unidos deu origem a um novo padrão sistêmico de riqueza, a financeirização, em que as operações financeiras ganham importância cada vez maior na gestão de ativos e passivos por parte das famílias e das empresas, e não apenas de instituições do mercado financeiro. Ao contrário do que sugerem interpretações mais recentes sobre esse fenômeno, isso não significa uma tendência do sistema à estagnação, mas um aumento da sua instabilidade característica, reforçando os momentos de expansão, mas também de contração. De fato, com a generalização e a

* Article received on April 10, 2017 and approved on September 18, 2017.

** Professors at the Institute of Economics - University of Campinas, Campinas, SP, Brazil. E-mails: bragajcs@uol.com.br; giulianoliveira@gmail.com; alex.wilhans@ gmail.com; simonededeos@gmail.com

${ }^{* * *} \mathrm{PhD}$ student in Economics at the Institute of Economics - University of Campinas, Campinas, SP, Brazil. E-mail: paulowwolf@gmail.com. 
dominância da lógica financeira as decisões de endividamento e de gasto das empresas e das famílias passaram a ser crescentemente sensíveis às oscilações correntes e esperadas nos estoques de riqueza, as quais, por sua vez, são sensíveis às mudanças dos preços dos ativos financeiros. Isso implica em transformações da relação entre Estado e mercados, com os bancos centrais e os tesouros nacionais tornando-se reféns da necessidade de evitar as perdas patrimoniais privadas e os efeitos perversos que elas podem exercer sobre os níveis de produto, renda e emprego da economia.

Palavras-chave: Financeirização; Capitalismo contemporâneo; Dinâmica econômica; Instabilidade; Desigualdade.

JEL F3, G1, E3.

\section{Introduction}

The neologism financialization has become part of the vocabulary of different economic strands in recent years. The use of the term in scientific publications, particularly those that criticize mainstream economics, has increased in the last two decades. However, its widespread use does not imply any consensual definition (Lapavitsas, 2011, p. 611). Although the term is intended to comprise a broad and heterogeneous set of social phenomena and does so, in general, based on a critical perspective, the meaning of these phenomena and their implications are addressed in many ways.

Financialization is often considered as a synonym for processes such as excessive speculation, exaggerated growth of the financial sector (Sawyer, 2016), privatization and financial liberalization. Thus, it is not uncommon to find expressions in the literature such as "financialization of commodities" (Cheng \& Xiong, 2014), "financialization of housing" (Aalbers, 2008), "financialization of education" (Eaton et al., 2016), "financialization of urban policy" (Lake, 2015), "financialization of consumption" (Montgomerie, 2009), "financialization of food" (Bruno, Büyükșahin \& Robe, 2017), "financialization of water" (Bayliss, 2014), "social financialization" (Sinclair, 2013), "financialization of labor relations" (Ruesga, 2012), among others. According to Toporowski (2015, p. 255), "[t]he use of the term in different contexts and with different meanings makes it of dubious analytical value".

Given this context, this paper aims to deepen the reflection on the phenomenon of financialization from a political economy approach, highlighting its relevance in comprehending the dynamics of contemporary capitalism. Based on Braga (1985, 1992, 1993, 1997, 2000, 2013), financialization is considered here as a systemic pattern of wealth that has a distinctive feature relative to previous stages of capitalism: the increasing share of financial assets in contemporary wealth. To be more specific: financialization, as a systemic pattern of wealth, establishes new ways of defining, managing and realizing the wealth, which affects the spending decisions of the main economic actors, impacts economic policies and thus the ups and downs of business cycles, as well as leading to crises. 
A financialized economy sets a new definition of wealth in the sense that an increasing share of total assets are financial assets traded in different markets - that is, a growing fraction of the financial assets has become fictitious capital (Marx, 1894). This subset of financial assets (stocks, public and private bonds, derivative contracts, structured products etc.), traded in different markets, has become increasingly complex and innovative. In this sense, wealth has become more and more abstract, purely financial, in the interaction between currencies, credit and real estate assets - while also taking into consideration real capital assets.

Financialization also defines a new way of managing wealth since, by presenting itself more as fictitious capital, it is managed in increasingly liberalized and deregulated financial markets. Given this context, crucial decisions on wealth management are based on the relationship between the major central banks, national treasuries, institutional investors, large banks and non-financial companies.

Finally, it consolidates a new way of realizing wealth since its circulation form is more and more defined by the M-M' circuit, i.e., money is advanced to obtain more money. From this, one cannot conclude that capital valorization by producing commodities is less relevant, or that there is a "decoupling" of the financial wealth relative to non-financial assets. This process simply suggests that the weight of nonoperating gains compared to operating ones from several economic units has become so important that it co-determines spending and borrowing decisions.

Financialization is the systemic pattern of wealth in capitalism that derived from the collapse of the Bretton Woods System. It is a pattern that, simultaneously, stimulated and resulted from a set of changes in monetary and financial systems. Among these changes one could mention the consolidation of a flexible-dollarstandard; the rise and prominence of institutional investors regarding the management of financial wealth ("collectivization" of individual savings); large banks turning into real "financial supermarkets"; development of the securitization process ("direct finance" and conversion of non-marketable assets into marketable assets); creation and development of several financial derivatives; exceptional growth of financial markets (bonds and securities); and the consolidation and expansion of financial deregulation and economic liberalization ${ }^{1}$.

Considering all of these large-scale structural transformations, the pursuit of monetary valorization of assets has begun to involve and characterize not only the logic of financial institutions, but also of companies in the so-called "productive sector", determining decisions on borrowing, spending and wealth allocation among different sets of assets. Even households are engaged in this process, since their wealth (collective savings) has also become increasingly financial - pension funds,

(1) For more information on the U.S. financial system characteristics, the main actor of the current systemic pattern of financialized wealth, see Braga and Cintra (2004). 
mutual funds, for example. In this sense, households' spending decisions have also been affected by the ups and downs of financial assets' prices, besides being influenced by income that derives from work as well as from the "wealth-effect" related to real states market dynamics. Paraphrasing Marx (1867, p. 423), it is a quantitative change that, at a certain point, operates a qualitative change in the capitalist system's operation ${ }^{2}$. Several types of fictitious capital developed considerably at the end of the 19th century with the emergence of joint-stock companies and the deepening of the banking systems in advanced economies, as highlighted by authors such as Marx (1894), Veblen (1904), Hobson (1906), Hilferding (1910) and Lenin (1917). However, in the 1970-1980 period, the share of financial wealth grew in significance, redefining capitalist wealth and expressively shaping the spending decisions of economic agents ${ }^{3}$.

This dimension of financialization has largely been referred to as "financeled capitalism" or "capitalisme dominé par les finances". It relates to the fact that the appreciation and depreciation of financial assets have been increasingly crucial to investment and consumption spending decisions, and thus to economic growth. In other words, the share of fictitious capital has become so important in contemporary capitalism that it increasingly determines spending decisions and, as a result, is the driving force behind modern economies. It is worth pointing out that this single dimension of financialization is often confused with the broader phenomenon. However, from an analytical point of view, taking financialization as a systemic pattern of wealth is more comprehensive, as it includes, as previously mentioned, new ways of defining, managing and realizing wealth.

In addition to this introduction, this paper is organized into five sections. The second section deals with the transformations in international economies that turned financialization into the pattern of wealth in contemporary capitalism. The third section presents a theoretical discussion on financialization and its impact on the dynamics of contemporary capitalism, as well as on the role of the state in this process. In the fourth section, this approach is contrasted with recent interpretations on the phenomenon. The fifth section presents data and selected indicators in order to illustrate the analysis. The conclusion is given in the sixth section.

\section{From the end of the Bretton Woods agreement to financialized capitalism}

In 1944, in Bretton Woods, United States, the agreement that defined the rules for international economic relations in the post-war period was signed. This agreement contributed to the economic and social progress that characterized the

(2) On this dialectical interpretative key, see Carneiro (2000).

(3) See Boyer (2000); Guttmann, (2008); Stockhammer (2008); Van Treeck (2009); Hein (2012) and Palley (2013). 
period known as the "Golden Age" of capitalism, with the geopolitical and economic leadership of the United States (Hobsbawm, 1995). In fact, in light of the threat of communist expansion and given the limits of economic liberalism in the early decades of the 20th century - after two world wars and the Great Depression - a new international monetary and financial arrangement was established, based on the golddollar standard and on the control of international capital flows. Generally speaking, the purpose was to ensure stable exchange rates and a favorable institutional environment for international trade in order to avoid permanent current account imbalances and to preserve the autonomy of national economic authorities to stimulate production and employment. This was related to the context of reconstructing the countries affected by the war and the industrialization of some peripheral countries (Helleiner, 1994, 2006).

Starting with the severe international economic turbulence at the end of the 1960s, the Bretton Woods arrangement came to an end in the mid-1970s when the gold-dollar standard was abandoned, followed by the liberalization policies of international capital flows and deregulation of markets, particularly the financial markets (Glyn, 2006). Given the emergence of new players, mainly Germany and Japan, the United States reaffirmed their hegemony by prioritizing the power of the dollar as the international currency and their financial market as the main space for fictitious capital circulation at a global level. In this way they subordinated other countries to their economic policy, albeit to different degrees. The end of the Bretton Woods system and the advent of "strong dollar diplomacy", which was most greatly expressed during the interest rate shock in 1979, inaugurated a new era of instability for the main countries, primarily those on the periphery of capitalism (Tavares, 1997; Braga; Cintra, 2004). The size of the American economy, its relevance in the international geopolitical scenario - particularly the opening and depth of its financial market, which indicate a complex network of connections presented by assets in dollar - provided the support for this currency in the new international monetary standard, which can be properly defined as a "flexible, fiduciary and financial" dollar standard (Prates, 2005, p. 269) ${ }^{4}$. Thus, the dollar has assumed a central role in financialized capitalism.

In fact, the end of the Bretton Woods system resulted not only in changing the rules of international economic relations, but also in a change in the operation of capitalism itself. Less and less limited to the political and institutional restrictions created in the postwar period, the increasing flexibility acquired by wealth - when assuming the form of financial assets - has stimulated inter-capitalist competition, accelerated concentration and centralization of capital, and created new opportunities for the transformation of money into more money. In this way,

(4) For more details on the determinants of the dollar as an international currency, see De Conti (2011); Helleiner (2008) and Metri (2004). 
fictitious capital - whose weight in wealth is growing - establishes the parameters of the capital operation as a whole ${ }^{5}$.

The development of fictitious capital was fostered by a set of financial innovations that followed the end of the Bretton Woods system and the subsequent strengthening of the process of liberalization of international capital flows, connected to the deregulation of markets around the world (Helleiner, 1994). These innovations allowed a larger number of actors to invest in more risky operations - in which the associated gains and losses have increased considerably - in several financial centers (Belluzzo, 1997).

Among these financial innovations, one can highlight the development of new products, such as financial derivatives, i.e., instruments that allow investors to negotiate, in the present, expected asset price variations ${ }^{6}$. The higher volatility of exchange rates, interest rates and asset prices after the end of the Bretton Woods agreement not only gave room for hedge operations in the derivatives market, but particularly for speculation and arbitrage operations, due to the low initial margin requirements, either as cash deposited into accounts or securities (Farhi, 1999). Regarding the new processes, it is important to highlight securitization, which enabled a whole spectrum of "originate-to-distribute" operations and thus the transformation of non-marketable assets into marketable assets in different types of financial markets (Bord, Santos, 2012; Allen, 2004; Kregel, 2007) ${ }^{7}$.

The expansion of these new products and processes was made possible by the role of credit rating agencies, such as Fitch, Moody's, and Standard \& Poor's. These agencies assess the capacity of different issuing agents to comply with financial commitments. Their ratings guide the allocation of financial wealth of different agents among several classes of assets. When the ratings change, it can abruptly change the composition of portfolios, with considerable effects on the assets' price levels, leading to self-fulfilling prophecy and contagion effects (Cintra; Cagnin, 2007).

It is important to mention that the emergence of these financial innovations has led to the consolidation of parallel financial markets, in the shadow of regulations - the so-called "shadow banking system" (Guttmann, 2016). In these markets, complex and risky operations are carried out, while its players remain on the margins of any regulation and supervision by authorities, or of any official mechanism to prevent liquidity crisis turning into a solvency crisis. Since these parallel financial markets are closely related - albeit ambiguously - to the regulated financial markets,

(5) On the category "fictitious capital" and its theoretical status, see Palludeto and Rossi (2016).

(6) Regarding derivatives as fictitious capital, see Palludeto (2016).

(7) Companies may also issue new securities guaranteed by receivables from these operations. Thus, we have a "financial pyramid" in this system, with the multiplication of financial contracts based on credit operations originally performed by banks. 
problems in one contaminate the others and the economy as a whole (Cintra; Farhi, 2008).

The broader development of fictitious capital was also stimulated by new agents, such as institutional investors - for instance, pension funds, investment funds and insurance companies, which manage households and firms' resources through the collectivization of their savings. Given the amount of resources managed by institutional investors, their decisions play a key role in determining the prices of financial assets, since they influence the expectations of other economic players. Small changes in the composition of their portfolios can generate considerable variations in these assets' prices, which are strengthened by changes in the composition of the portfolios of other players (Oliveira, 2009).

Taking Hilferding's (1910) category of "finance capital" as the union of partial forms of capital, one can describe contemporary capitalism, from both a logical and historical perspective, based on this category. In an environment of increased inter-capitalist competition all over the world, concentrated and centered capitals - as exacerbated finance capital - play simultaneously in the sphere of production and circulation of goods and services, as well as in the financial sphere, through the purchase and sale of financial assets. The effective joint operation of productive, commercial and financial accumulation is what distinguishes this system and determines its current dynamics ${ }^{8}$.

\section{Financialization as a systemic pattern of wealth}

Financialization should be understood as a systemic pattern of wealth that implies the predominance of financial logic in the decision-making process of relevant players in the capitalist system (Braga, 1993, 1997). It is a pattern in which the trading of financial assets is carried out not only by financial institutions, but also by households and productive enterprises, affecting their decisions on borrowing, spending and allocation of wealth among different asset classes, with different degrees of liquidity and expected returns.

For all key economic agents, finance has become an important element in the general financial calculation that guides spending decisions - and, consequently, borrowing decisions. Thus, financialization is a pattern of wealth that focuses on earnings in the financial sphere - either interest payments or asset price appreciation - not as an anomaly, but as a structural aspect of a system that tends to expand the flexibility of wealth in its valorization process. Given this context, if one considers that interest compensation, lato sensu, is inherent to capitalism, and that it is enhanced by financialization, its eradication would mean the end of the system itself.

(8) For more details on the historical process that led to this period, see Braga (1997). 
In other words, the "euthanasia of the rentier" as proposed by Keynes, would mean the euthanasia of capital itself. According to Braga (1997, p. 237):

It is a systemic pattern because it is built by fundamental components of the capitalist organization, intertwined so as to establish a structural dynamics according to principles of a general financial logic. In this regard, it does not come only from the praxis of segments or sectors (...) but, on the contrary, it has marked the strategies of all relevant private agents, conditioned the operations of public finance and government expenditures, and changed the macroeconomic dynamics. Ultimately, it has been intrinsic to the system such as it is now configured.

In this context, a significant number of households has started to acquire directly or indirectly, through institutional investors such as pension funds, investment funds and insurance companies - larger amounts of financial assets, which have come to account for a growing share of their net worth - traditionally restricted to real estate and durable goods (Coutinho, Belluzzo, 1998; Lund et al., 2013; Credit Suisse Research Institute, 2016). A similar process has taken place with enterprises, mainly large business groups, particularly those organized as holding companies, who have been guided by the following function:

$$
\text { Fo }=\mathrm{f}(\mathrm{Zgs}, \mathrm{Itp}, \mathrm{X}, \mathrm{Cgv}, \mathrm{Fg})
$$

where Zgs = production and trade of goods and services; Itp = investment in technical progress, with the creation of new products, new processes, and new organizational forms; $\mathrm{X}=$ internationalization through trade; $\mathrm{Cgv}=$ internationalization through investment and, more specifically, breaking up the value chain among different countries; and $\mathrm{Fg}=$ general finance, which may have operational purposes when related to the core business; and non-operational, when not related to those activities, but focused on speculation and arbitrage in financial markets ${ }^{9}$. Thus, finance has become a way of accumulating wealth that is increasingly relevant in contemporary capitalism. This phenomenon has led to the creation of large departments that enable highly complex financial management to quickly change fundraising and allocation strategies (Braga, 1997).

In this way, large corporations, including the "non-financial" ones, have become: i) multinational companies, because they are in different countries; II) multi-functional, because they operate in different branches of activities; and iii) multi-sector, because they perform in different activities within each branch. Therefore, their profitability includes not only the so-called "operating earnings,"

(9) According to Serfati (2008, p. 53), the expansion of intangible assets in transnational corporations in recent years -intellectual property rights being a paradigmatic example - also reveals the centrality of finance in the operation of these corporations, since such assets are considered financial assets - and they are indirectly valued at the stock market. 
that is, revenues from the production and sale of goods and services, but now also from non-operating earnings, i.e., from operations with financial assets (Braga, 2000). Thus, in contemporary capitalism, from the point of view of large corporations, there is no reason for the split between productive companies and nonproductive ones, or even between productive and financial capitalists, since financialization - as a systemic pattern of wealth - means the consolidation of different forms of capital under financial dominance.

In this new systemic pattern of wealth, the main competition is not among companies from within the same country, same branch or from the same activity in the so-called microstructure. The main competition is, however, among large business groups that perform in different countries, branches and activities, in the so-called mesostructure. These companies interact with households, banks and other financial institutions, as well as with central banks and national treasuries, in the socalled macrostructure, thus determining the dynamics of contemporary capitalism. Macrostructure, as given in this study, refers to the space where monetary and financial operations take place - carried out by the main economic actors -, and where the parameters that dictate expenditure and borrowing decisions are defined.

While becoming a systemic pattern of wealth, financialization has implied the emergence of an increasingly exceptional amount of fictitious capital - nationally and internationally - in several financial centers in the world. Thus, processes of asset inflation and deflation have become recurring, exacerbating the intrinsic instability of capitalism, given that expenditure and borrowing decisions made by companies and households have become increasingly sensitive to current and expected fluctuations in the financial asset prices - the so-called "wealth effect." The depreciation of these assets thus reduces the wealth of the players, resulting in fewer loans and lower expenditure, with negative effects on the effective demand and vice versa (Coutinho; Belluzzo, 1998; Minsky, 1986; Kregel, 1997).

This means that, while affecting expenditure decisions, the generalization of the financial logic influences the dynamics of production, income and employment, regulating the concrete living conditions in contemporary capitalism. This dynamic is increasingly conditioned by wealth effects caused by changes in asset prices, a process that occurs quickly and aggressively given changes in uncertainty, in the general state of expectations and in the degree of liquidity preference of the actors. It is worth highlighting that it is not only - as pointed out by Minsky $(1975,1986)-$ that finance sets the pace of the economy. Financialization is a major change that has redefined the structures and dynamics of the economic system. Financialized capitalism is characterized by an exacerbated tension between expansion and crisis, already typical of the capitalist system (Kindleberger, 1989; Braga, 1997). 
This process is enhanced by the activities of banks and quasi-banks (institutional investors). Regarding the banks, this is mainly because they increase the possibility of wealth expansion as fictitious capital by providing credit to financial operations ${ }^{10}$. In the case of quasi-banks, as they deal with a significant amount of financial wealth, their operations change financial asset prices and influence the business cycle (Guttmann, 1998).

The impact of finance on business cycles is enhanced by the extremely high interdependence of the portfolios of households, non-financial companies, banks and other financial institutions in several countries. As stated by Minsky $(1975,1986)$, capitalist economies that rely on complex financial systems can be defined as a set of interrelated balance sheets. In fact, the decisions independently taken by economic agents affect other actors all over the world, not only when they make profits, but also in the case of losses (Minsky, 1986; Braga, 1997, 2000; Belluzzo, 2013).

The consolidation of financialization as a systemic pattern of wealth has implied major changes in the relationship between the state and the market. In this situation, the state assumes a central role, guaranteeing the process of financial wealth accumulation. In terms of central banks, they not only act as lenders of last resort, but also as market makers of last resort. Concerning the national treasuries, besides being the key link for the central banks to bail out financial institutions during crises, they are crucial to avoiding depressions, reducing taxes and increasing expenditures in order to encourage private sector spending or, at the very least, to compensate its retraction. However, the negative fiscal impact caused by crises and, sometimes, by counter-cyclical operations, leads the market to put pressure on the state in order to balance the fiscal budget, with devastating impacts on society as a whole. In contemporary financialized capitalism, "privatizing profits" in optimistic periods and "socializing losses" during crises become of an extreme nature (Braga, 2009).

\section{A critical analysis of some recent approaches to financialization}

The pioneer concept of financialization, proposed by Braga $(1985,1993$, 1997 $)^{11}$, contrasts with new proposals, which have transformed the recent debate on the phenomena into a "Tower of Babel". Without intending to present a comprehensive review of the literature on the topic, the current section highlights

(10) It is worth noting that banks have become real "financial supermarkets". In fact, banks increasingly participate in the structuring of corporate and government funding operations through the issuance of securities. Banks are also important buyers of these papers, which represent an increasing share of their assets (Oliveira, 2009).

(11) Although Braga (1985) did not use the term "financialization" to denominate the phenomenon under analysis here, the author put it clearly: "Valorization and competition operate under the dominance of a financial logic, which means - among other things - that centralized capitals manage simultaneously several types of assets ranging from productive assets to financial assets" (Braga, 1985, p. 374). 
just a few emblematic interpretations of financialization, which contrast with the original approach suggested in this study ${ }^{12}$.

According to Foster (2007), the origin of the term financialization is uncertain, but was first used in the early 1990s. As evidence, Foster (2007) mentions the studies by Phillips $(1993,1994)$, although does not refer to previous works (before the 1990s) that used the term. According to the author, even though these studies did not use the term financialization, some of them drew attention to the growing importance of finance in capitalism. He also states that special attention should be given to the work of Sweezy and Magdoff (1972) - originally published in 1965 by Magdoff in the Socialist Register - in which the authors highlight the increasing role played by finance in the capitalist system.

In more recent years, according to Lapavitsas $(2011)^{13}$, the most widespread concept of financialization is that presented by Epstein (2005), in the introduction of one of his books in which he presents several papers on the topic. According to Epstein (2005, p. 3), the definition, which is based particularly on Krippner (2004, 2005), is given as: "[...] financialization means the increasing role of financial motives, financial markets, financial actors and financial institutions in the operation of the domestic and international economies." Nevertheless, the different chapters in this book highlight different perspectives on financialization, either from a conceptual perspective or regarding the various implications, each one pointing to individual parts of the broader phenomenon.

Among these different definitions, one can emphasize those derived from the idea of progressive expansion of financial gains at the expense of profits from the production and trade of goods and services. According to this view, productive capital is on one side, and unproductive capital (rentier capital) on the other - the latter taking the place of the first. As a result, there would be an inexorable tendency towards economic stagnation - except perhaps in the case of economies with strong monetary and financial power ${ }^{14}$ (Chesnais, 2005; Plihon, 2005).

In general, these visions do not appear to focus on the concept of capital as a value that increases itself, generating more money in different spheres. The fact that households and companies - and not only banks and other financial institutions

(12) For an attempt to systematize the literature on financialization, see Van der Zwan (2014).

(13) Some analyses relying on Keynesian and Marxist assumptions usually highlight "rent-seeking" to address financialization (Eptein, 2005; Crotty, 1990; Pollin, 2007; Palley, 2013; Chesnais, 2005; Plihon, 2005; Aglietta; Rebérioux, 2005). For these authors, the increase in financial gains at the expense of earnings from the production of goods and services have negative effects on investment, production and economic growth which, according to some of them, may lead to economic stagnation. Regarding the relationship between financialization and stagnation, see also Stockhammer (2008); Duménil and Lévy (2011), and Magdoff \& Foster (2014).

(14) Basically speaking, these are the countries and/or economic areas that have international currencies, i.e., those that fully meet the three classic functions of a worldwide currency such as the U.S. dollar. 
- reap financial gains through the active trading on financial markets does not imply a collapse in the production and trade of goods and, therefore, in income and employment. In fact, this phenomenon contributes to generating an even more unstable system, with periods of great expansion and significant contraction, since it relies on a more complex net of credit-debt relations, with the financial assets as the most visible expression of this system. The recent history of capitalism is extremely clear in this regard: while the frequency and depth of economic crises have increased in several economies all over the world, there were relatively long periods of economic expansion - as in the United States in the 1990s and in the 2000s, as well as in several European Union economies from the mid-1990s on.

These perspectives become even more problematic when based on the assumption that the expansion of finance is a consequence of insurmountable obstacles to the accumulation process in the spheres of production and circulation of goods, resulting from underconsumption, exhaustion of investment opportunities or from the weakening of technical progress, for example. As a consequence, the growing profitability in the financial sector would be an alternative for owners of wealth in contemporary capitalism in order to compensate for the decreasing profitability opportunities in the productive sector.

Taking another perspective, this paper supports the idea that financialization does not result from the deterioration of the conditions of production and circulation of goods and services in capitalism. Financialization is, indeed, a logical and a historical result of a system driven by the incessant search for new ways to accumulate wealth, considering the increased inter-capitalist competition - and, consequently, of the processes of capital centralization and concentration - in a USled international economy based on the liberalization of international capital flows and on the deregulation of markets, and driven by the emergence and development of innovations on a global scale.

The concept of financialization as a systemic pattern of wealth does not consider financial dominance as a deviation relative to the genuine capitalist system that based on the production and circulation of goods and services. One must avoid a dualistic vision on the existence of "good capital" - that relies on the production and trade of goods and services - and "evil capital", i.e., based on finance. Capital is in constant search of new ways to increase its own value, and so operations in the financial sphere are as legitimate - from the point of view of the capital logic - as those in industrial and commercial spheres. Moreover, it is part of the immanent development of capital as value that valorizes itself, such as pointed out by Marx (1867), to assume increasingly liquid forms, while at the same time it widens the space for concentration and centralization, in order to strengthen control over all spheres of material reproduction. 
As previously pointed out, the ultimate purpose of capital is valorization in monetary terms. It is also worth highlighting that the exceptional growth of operations with financial assets performed by all relevant actors of the system has not blocked the expansion of investment, consumption, production and technical progress. "Fictitious" and "real" capital comprise a unique, complex and contradictory totality, and influence each other throughout the business cycle, reflecting the contradictory nature of capital expressed in the permanent tension between expansion, contraction and crisis (Perelman, 1990). These contradictions become more evident and resolve themselves during the crises, only to reappear in the future in a new position, since they are inherent to capitalist economies (Braga, 2009). Capitalism instability is thus reinforced by financialization.

Understood in this way, financialization does not imply economic stagnation. It does not block the system in terms of productive, technological and organizational changes. Financialization implies an increase in the instability inherent to capitalism, with periods of strong economic expansion and also deep crisis. This more recurrent succession of mania, panic and crashes in recent decades implies a stronger role of the state in order to take actions to prevent or, at least, to restrain private losses, either through central banks, acting as big banks, or through the national treasuries, acting as big government (Minsky, 1975, 1986).

\section{Financialization, instability and inequality}

As evidence of financialization, Graph 1 presents the financial assets of households, nonprofit organizations and non-financial corporations in the United States directly or indirectly owned - through institutional investors - and Graph 2 shows the financial assets to the total assets of these agents between 1951 and 2016. One can observe that household and nonprofit organizations, as well as non-financial corporations, substantially increased their positions in financial assets at the beginning of the 1980s. This upward trend was only interrupted during the 2001 crisis, with the collapse of the dot-com bubble and the terrorist attacks in New York, and in 2008, due to the crisis in the same year. As a result, the amount of financial assets owned by households and nonprofit organizations increased from US\$ 20 trillion, in January 1980, to US\$ 73 trillion, in July 2016, while the financial assets of non-financial corporations increased from US\$ 4 trillion to US\$ 19 trillion, in the same period.

In fact, the importance of financial assets started to grow in the 1980s, in the case of non-financial corporations, and in the early 1990s, for households and nonprofit organizations. In both cases, the process was affected by the 2001 and 2008 crises. Regarding non-financial corporations, financial assets increased from $26.7 \%$ in 1980 to $46.1 \%$ of total assets in 2016, while for households and nonprofit organizations, financial assets increased from $61.0 \%$ to $69.5 \%$ of total assets in the same period. 
Graph 1

Financial assets (US\$ billion) - household and nonprofit organization (U.S.) - 1951-2016*

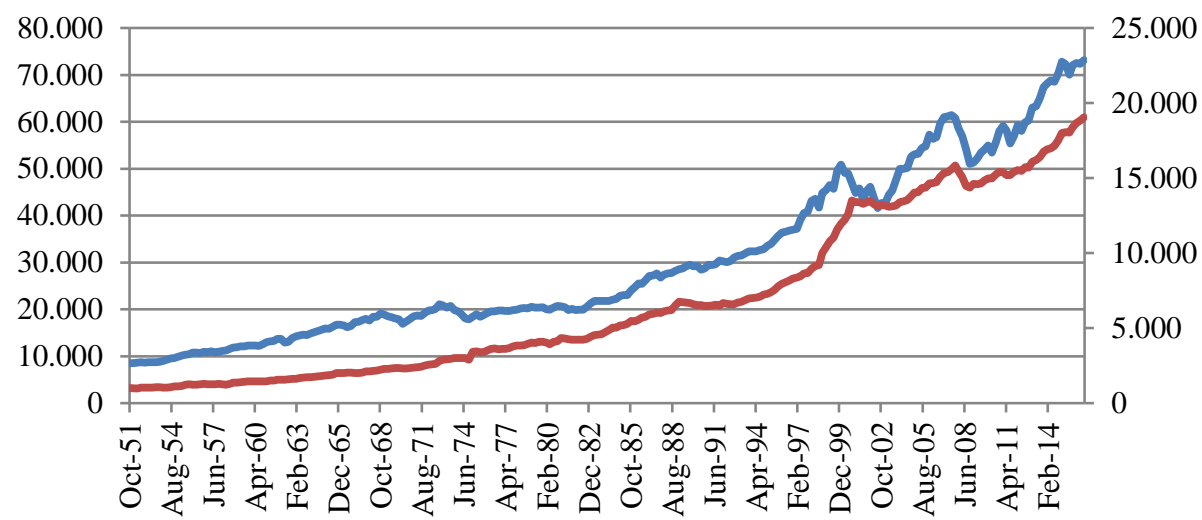

Total Financial Assets of Households and Nonprofit Organizations (Left)

Total Financial Assets of Nonfinancial Corporate Business (Right)

* Constant dollars (2016).

Source: Federal Reserve System. Authors' own elaboration.

Graph 2

Financial assets to total assets (ratio) - household and nonprofit organization (U.S.) - 1951-2016

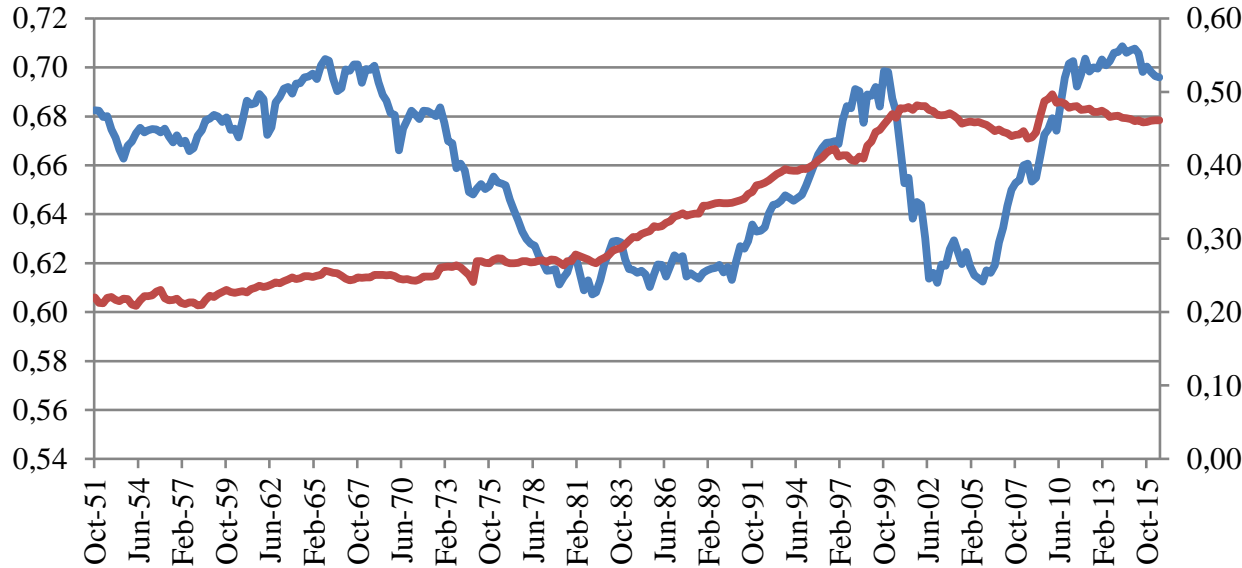

Total Financial Assets in relation to Total Assets of Households and Nonfinancial Organizations (Left)

Total Financial Assets in relation to Total Assets of Nonfinancial Corporate Business (Right)

Source: Federal Reserve System. Authors' own elaboration.

As expected, this process affected the trend of non-operating revenues of non-financial corporations in relation to their operating gains. Graph 3 shows the 
financial income ${ }^{15}$ of non-financial corporations between 1969 and 2015 as a percentage of gross operating surplus ${ }^{16}$. The importance of financial income of nonfinancial corporations increased considerably relative to gross operating surplus, up until 2001. After this period, a downward trend was observed, which was reinforced by the 2008 crisis. It is worth pointing out that financial income ratio increased from $15 \%$ in 1980 to almost $25 \%$ in 1989 , falling to around $15 \%$ in 2003 , and to $8 \%$ in 2015. Nevertheless, aside from the most recent crisis period, there was a significant increase between the beginning of the 1970s and the 1990s.

Graph 3

Financial income of U.S. nonfinancial corporations (\% of gross operating surplus) - 1969-2015

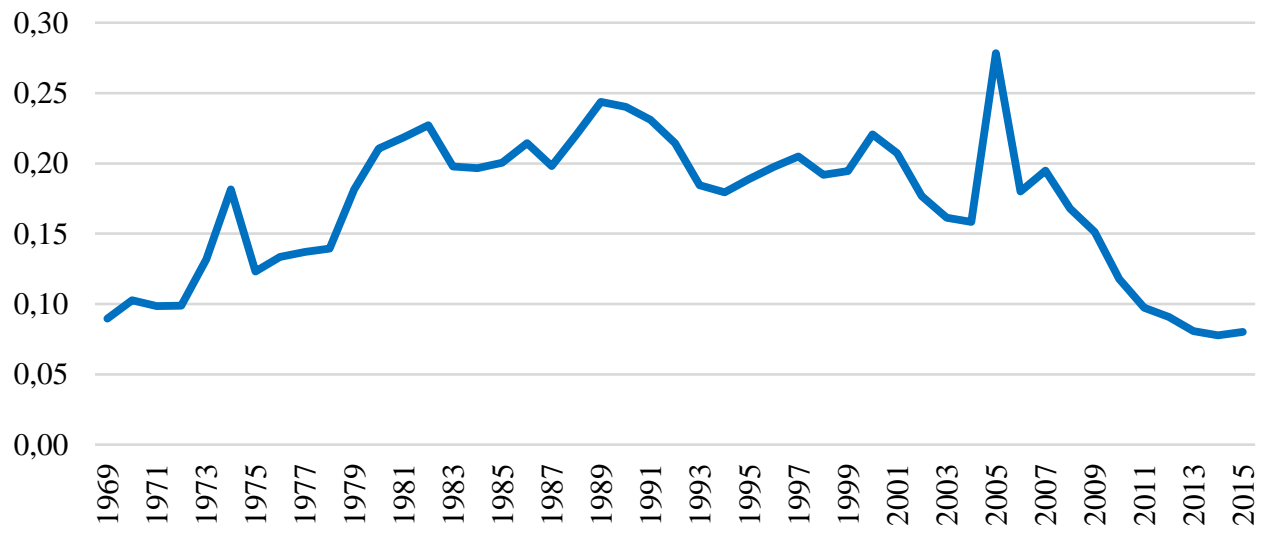

Source: Bureau of Economic Analysis. Authors' own elaboration.

It is important to note that the trend of financial income ratio of non-financial corporations is closely related to the performance of financial assets traded, whose prices have experienced large fluctuations since the liberalization of international capital flows and deregulation of financial markets, as well as the emergence and development of product and process innovations.

In this regard, Graph 4 shows the stock market turnover ratio in markets all over the world between 1976 and $2014^{17}$. This turnover has increased considerably since the beginning of the 1980s, a process that only stopped with the 2001 and 2008

(15) Financial income comprises the sum of interests and dividends.

(16) Gross operating surplus is a profit-like measure that shows business income after subtracting total intermediate inputs, compensation of employees and taxes on production and imports less subsidies from total industry output.

(17) Turnover ratio is the value of domestic shares traded divided by their market capitalization. The value is annualized by multiplying the monthly average by 12 . According to the World Federation of Exchanges (2013, p. 4): "A company is considered domestic when it is incorporated in the same country as where the exchange is located. The only exception is the case of foreign companies which are exclusively listed on an exchange, i.e. the foreign company is not listed on any other exchange as defined in the domestic market capitalization definition". 
crises. In fact, the stock market turnover ratio increased from almost $40 \%$ in 1980 to approximately $150 \%$ in 2000 , and then to almost $250 \%$ in 2007 . In spite of the recovery process in recent years, the turnover was still only at $150 \%$ in 2016.

\section{Graph 4}

Turnover ratio of domestic shares (World, \%) - 1976-2015

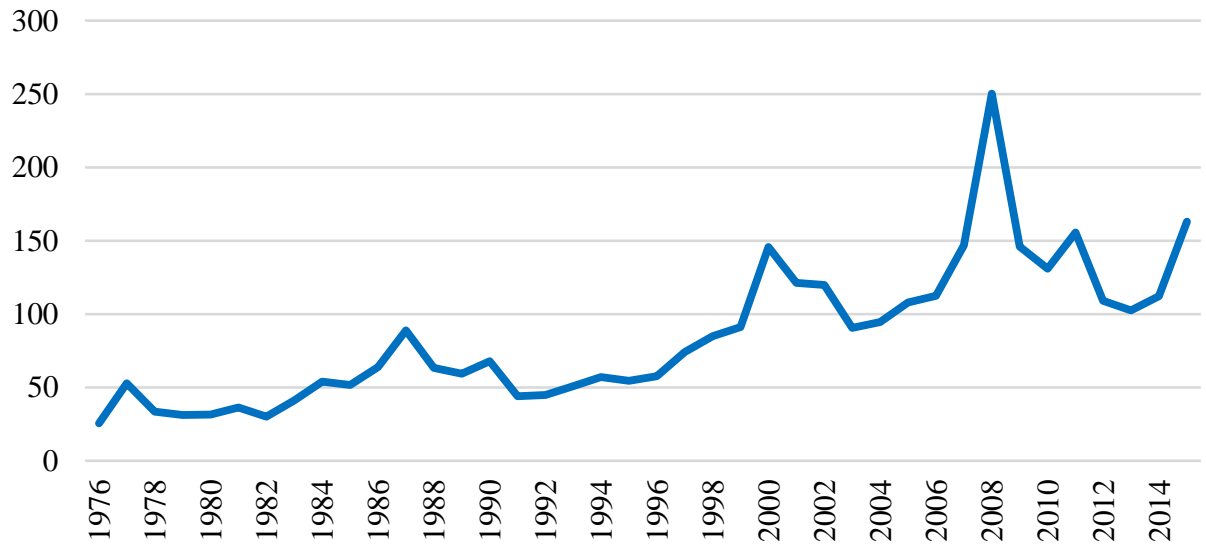

Source: World Federation of Exchanges. Authors' own elaboration.

As one would expect, the pace of business affected the stock price in the period mentioned. Graph 5 shows the capitalization of domestic corporations in relation to the world's GDP between 1975 and 2015. As in the case of turnover, the value of the shares of domestic companies increased quickly and significantly at the beginning of the 1980s until the crises in the 2000s. Market capitalization increased from almost 30\% to approximately 120\% of the world's GDP between 2000 and 2007. Even considering the recovery process, it is worth highlighting that the domestic value of listed companies was about 100\% of the global GDP in 2016.

\section{Graph 5}

Market capitalization of listed domestic companies (World \% of GDP) - 1975-2015

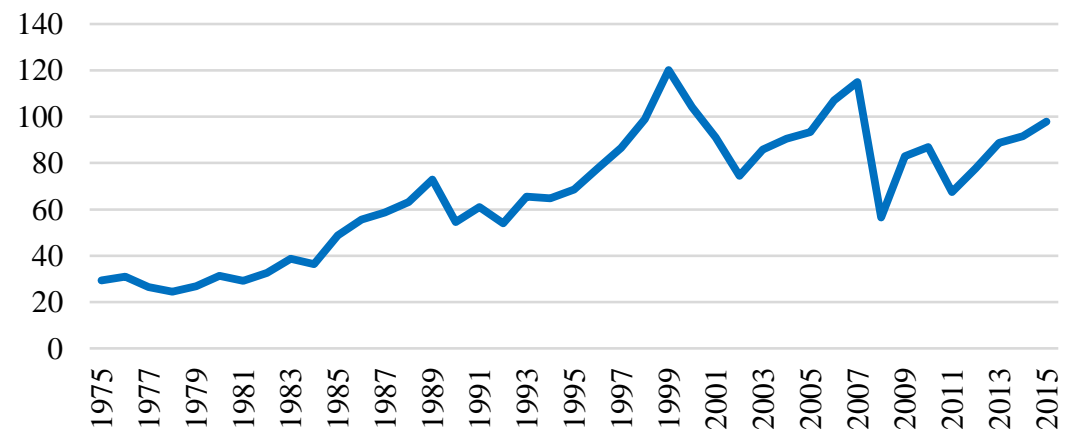

Source: World Federation of Exchanges. Authors' own elaboration. 
The 2001 and 2008 crises had a significant impact on the financial markets. The impacts would have been even worse, however, if it were not for the quick responses from central banks and national treasuries, in order to avoid an even deeper devaluation of the financial wealth and thus harmful effects on credit, consumption and investment.

Graph 6 presents the assets of the Federal Reserve System (Fed), the central bank of the United States, between 2007 and 2016. At the beginning of the crisis, the Fed sought to prevent the liquidity crisis from turning into a solvency crisis of financial market institutions - this was carried out through the provision of liquidity to banks and quasi-banks, mainly insurance companies and investment banks. This is shown in Graph 6 with the increase in liquidity facilities with the Central Bank Liquidity Swaps, the Commercial Paper Funding Facility, and the Term Auction Facility as the most important ones. When the worst of the crisis was over, the Fed continued to pump liquidity into the system in an attempt to stimulate credit and the level of economic activity. These operations, known as Quantitative Easing (QE), occurred in three rounds. The first began in November 2008, the second in November 2010, and the third in September 2013.

Graph 6

Federal Reserve System - Total Assets (US\$ billion) - 2007-2016

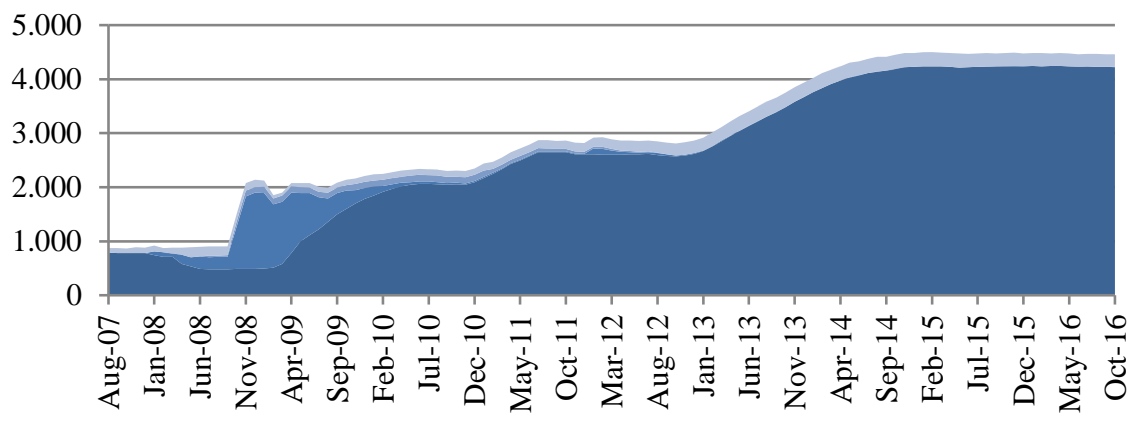

$\square$ Securities Held Outright $\quad$ All Liquidity Facilities*

$\square$ Support for Specific Institutions** $\square$ Other Assets

* Includes: Term Auction Credit, Primary Credit, Secondary Credit, Seasonal Credit, Primary Dealer Credit Facility, Asset-Backed Commercial Paper Money Market Mutual Fund Liquidity Facility; Term Asset Backed Securities Loan Facility; Commercial Paper Funding Facility; Central Bank Liquidity Swaps.

** Includes: Maiden Lane LLC; Maiden Lane II LLC; Maiden Lane III LLC e support to AIG.

Source: Federal Reserve System. Authors' own elaboration.

Graph 6 depicts the increase of Securities Held Outright, which comprises the securities bought by the Federal Reserve from banks and other financial market 
institutions. These QE operations are unique not only because of the amount of securities purchased, but also because of their quality. In fact, if in the past the Fed used to hold only lower-risk US Treasury securities, this has changed and the central bank portfolio also began to include higher-risk private securities. One last thing to notice in Graph 6 are the operations called Support for Specific Institutions, which includes the rescue operations of financial market institutions, such as the investment bank Bear Stearns and the insurance company American International Group (AIG) (Bullio, 2015; Matthews, 2015).

Graph 7, in turn, shows the Fed's liabilities during the same period. The counterpart of the increase in Fed assets, and as a consequence of its liquidity provision to the financial market, was the increase in its liabilities led by the increase in bank reserves. This is due to the fact that, when buying the assets from banks, the Fed increases liquidity available to these institutions in order to stimulate them to enlarge the supply of credit for consumption and investment. Therefore, the Fed's operations after the crisis led to a rapid and pronounced rise in the monetary base.

Graph 7

Federal Reserve System - Total liabilities (US\$ billion) - 2007-2016

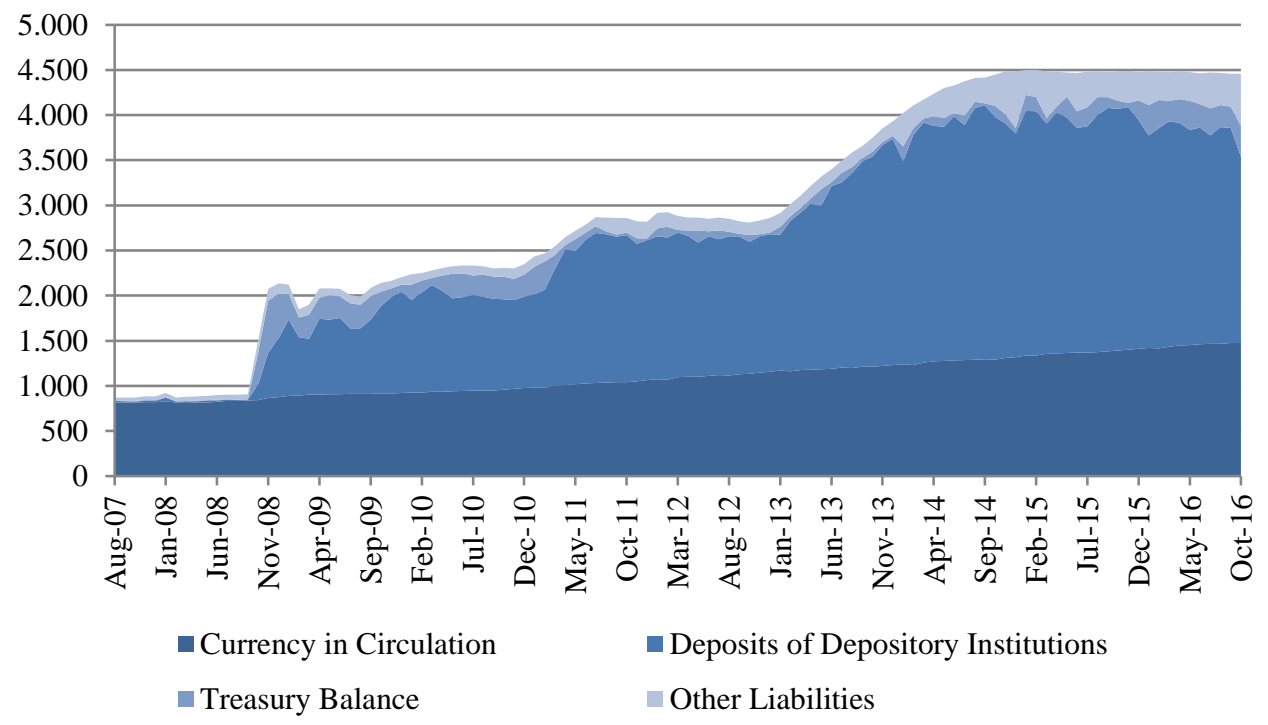

Source: Federal Reserve System. Authors' own elaboration.

In addition, the US Treasury acted promptly. Besides reducing taxes and increasing expenditure to stimulate the private sector and/or to compensate its retraction, the US government rescued the financial and nonfinancial institutions under stress by buying assets and providing them with liquidity. Given the extension of the crisis, these actions had considerable negative effects on the fiscal results. As 
shown in Graph 8, he public deficit increased, from zero in 2007 to $11 \%$ of GDP in 2009 , which in turn led to an increase in the public debt, from $60 \%$ to $90 \%$ of GDP during the same period.

As already pointed out, financialization as a systemic pattern of wealth results in an increase in the instability that characterizes the capitalist system, reinforcing the movements of expansion, but also of contraction. During this process, some groups benefit more than others. The high concentration of financial wealth leads to a considerable increase in social inequality, even more so in the absence of adequate policy interventions. Rowthorn (2014) and Roberts (2015), based on data presented in Piketty (2014), when criticizing this author's explanations of the issue, state that a significant part of the increase in wealth inequality in the last decades is a consequence of the valorization of financial assets. In fact, as Erturk et al. (2008, pp. 22-23) emphasized, financial assets are even more unevenly distributed than real estate and other assets. Thus, the gains from the valorization of financial assets and from the increase in income associated to this process reinforce the unequal distribution of income and wealth over time.

Public sector primary balance and public sector debt (US, \% of GDP) - 2001-2016

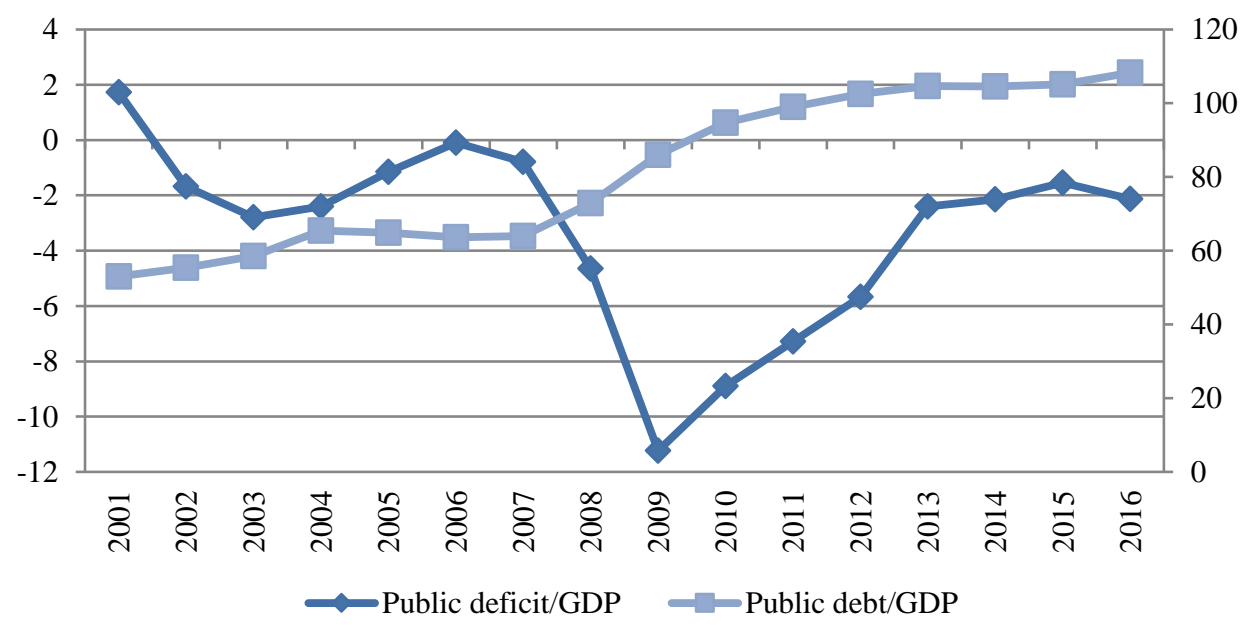

Source: IMF. Authors' own elaboration.

Graph 9 shows the Gini Index for the OECD countries between 1985 and 2013. Although developed countries tend to show a lower degree of income concentration relative to underdeveloped ones, most of the countries considered have experienced a worsening of income distribution. 
Graph 9

Gini index (0 to 1$)-1985-2013 *$
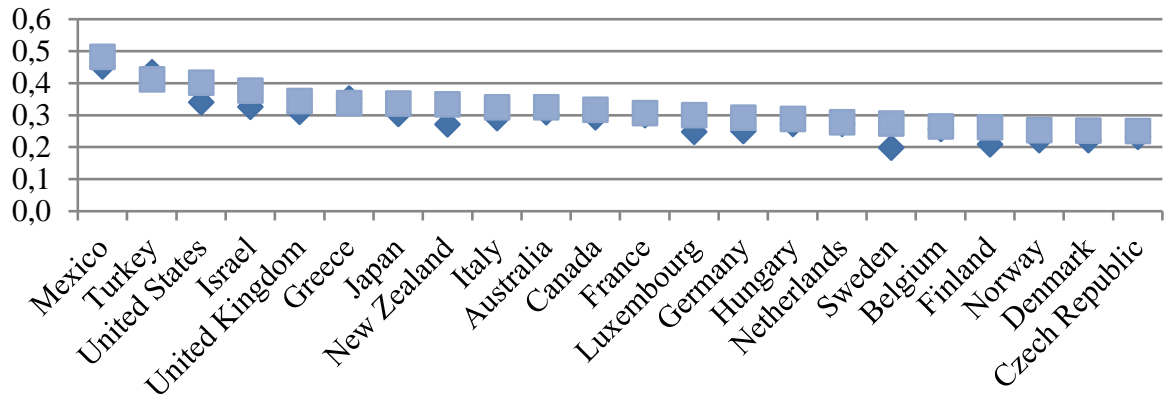

- 19852013 or latest

* 2013 or for the last year available.

Source: OECD. Authors' own elaboration.

Graph 10 shows, in turn, the level of income of selected income groups between 1985 and $2010(1985=1)$. Although the level of income of all groups considered increased up until the outbreak of the crisis in 2007, the income of the richest groups did so more rapidly and sharply relative to the income of the poorest groups, in the period considered. In fact, the income received by the poorest $10 \%$ in 2007 was $22 \%$ higher than in 1985 , while the richest $10 \%$ received, in $2007,54 \%$ more than they did in 1985. It is also important to observe that after the outbreak of the crisis, the income of the poorest groups fell quickly and pronouncedly relative to the income of the richest groups. In fact, the income received by the poorest $10 \%$ in 2011 was $14 \%$ higher than in 1985 , while the richest $10 \%$ had, in $2011,51 \%$ more than the income received in 1985 .

Level of income of selected income groups $(1985=1,00)-1985-2011$

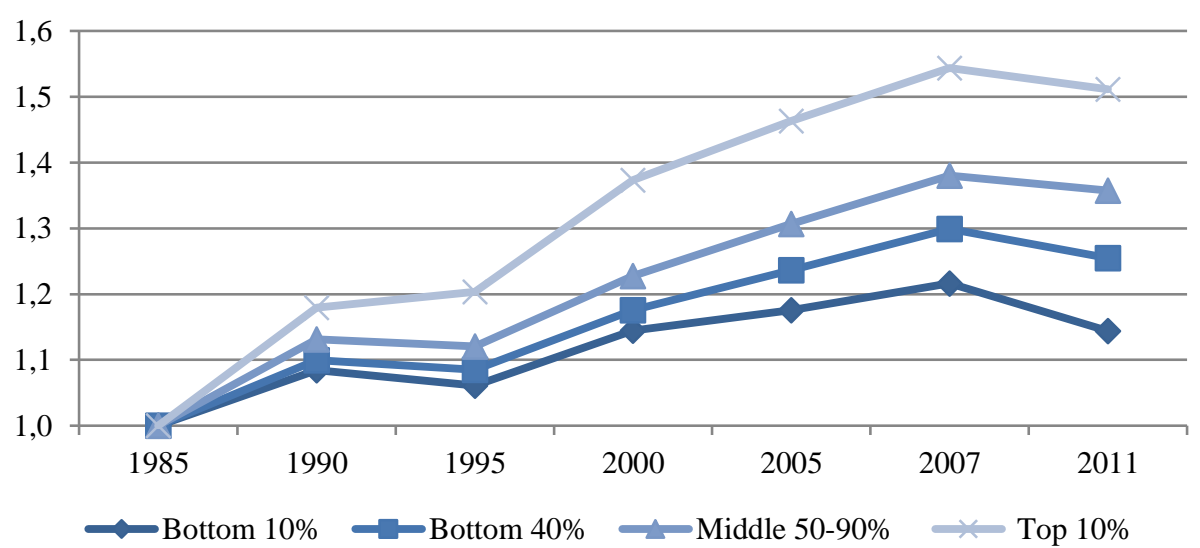

Source: OECD. Authors' own elaboration. 
Lastly, Graph 11 shows the level and the composition of household wealth per quintiles in the OECD countries in 2010. It shows not only that the fifth quintile, which corresponds to the richest $20 \%$, hold the greatest portion of wealth in the countries considered, but also that for these countries, financial assets are more important (as a share of total assets) than for the others, which indicates that financialization was associated with the increase in income and wealth inequalities in the period. In fact, while for households of the first quintile, which corresponds to the poorest $20 \%$, financial assets accounted for $18 \%$ of total assets, for households of the fifth quintile, which corresponds to the richest $20 \%$, these assets comprised $33 \%$ of total assets.

Graph 11

Level and composition of households' wealth by quintile (US\$ thousand) - 2010

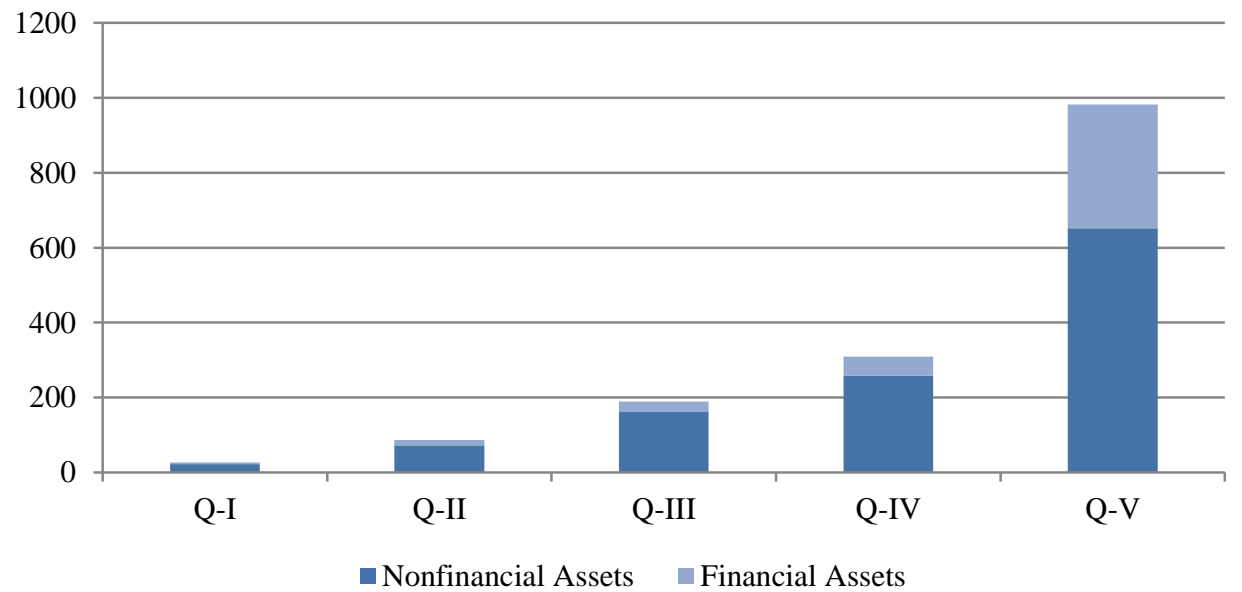

Source: OECD. Authors' own elaboration.

\section{Conclusion and final remarks}

Financialization is the systemic pattern of wealth in capitalism in place since the collapse of the Bretton Woods agreement. It is a pattern in which the valorization of financial assets involves not only the operations carried out by financial institutions, but also by households and productive enterprises, affecting their decisions on borrowing, spending and allocation of wealth among different classes of assets, with different degrees of liquidity and expected returns. In fact, financialization is the result of the exacerbation of the logic of finance capital considered here as the union of the different forms in which capital manifests itself, as proposed by Hilferding (1910). In other words, money that simultaneously generates more money in the productive, commercial and financial spheres.

The end of Bretton Woods has resulted in a set of changes that have enabled the consolidation of financialization as a systemic pattern of wealth, meaning that: 
1) a larger share of the wealth of households and companies, and not only of banks and other financial institutions, is comprised of financial assets; 2) new ways of defining (currency-credit-assets), managing (financial macro-structure) and realizing wealth (increased importance of monetary and financial assets over the non-financial ones) were established under the dominance of the financial logic; 3) capitalist calculation is based on a general financial calculation, which includes not only operating gains, but also, and increasingly, non-operating ones, especially those resulting from the trade of financial assets; 4) this pattern of wealth has strongly influenced the economic dynamics, given the increasing importance of the value of financial assets on investment and consumption spending decisions, and, by extension, the effective demand. This exacerbates the tension between expansion and crisis, already typical of the capitalist system; and (5) the relevant amount of financial wealth in the portfolios of various economic actors has made the countercyclical intervention of national states increasingly necessary in the context of crisis. However, these interventions often do not have the desired effects, since they impact fiscal results before economic recovery has been re-established.

Thus, and contrary to the most recent interpretations of financialization, it can be concluded that the widespread financial logic, impacting all key actors in the system, does not imply an inexorable tendency of the system to stagnate, but rather an increase in its instability, exacerbating the ups and downs of business cycles, as well as crises. This is because expenditure and borrowing decisions of companies and households have become increasingly sensitive to current and expected fluctuations in financial asset prices, which determine changes in output, income and employment levels. This new historical and logical context in the economy, one of much greater complexity, implies a more prominent role of the state through central banks and national treasuries in order to relieve the perverse economic and social effects of the process, even though the political action brings about new challenges. The final result of this process is totally undetermined and open to history.

\section{References}

AALBERS, M. B. The financialization of home and the mortgage market crisis. Competition \& Change, v. 12, n. 2, p. 148-166, 2008.

AGLIETTA, M.; REBÉRIOUX, A. Corporate governance adrift: a critique of shareholder value. Cheltenham; Northampton, MA: Edward Elgar Publishing, 2005.

ALLEN, L. The Basel capital accords and international mortgage markets: a survey of the literature. Financial Markets, Institutions \& Instruments, v. 13, n. 2, p. 41108, 2004.

BAYLISS, K. The financialization of water. Review of Radical Political Economics, v. 46, n. 3, p. 292-307, 2014. 
BELLUZZO, L. G. M. O dinheiro e as transfigurações da riqueza. In: FIORI, J. L.; TAVARES, M. C. (Ed.). Poder e dinheiro: uma economia política da globalização. São Paulo: Vozes, 1997.

BELlUZZO, L. G. M. O capital e suas metamorfoses. São Paulo, SP: Editora Unesp, 2013.

BORD, V.; SANTOS, J. A. The rise of the originate-to-distribute model and the role of banks in financial intermediation. Federal Reserve Bank of New York Economic Policy Review, v. 18, n. 2, p. 21-34, 2012.

BOYER, R. Is a finance-led growth regime a viable alternative to Fordism? A preliminary analysis. Economy and Society, v. 29, n. 1, p. 111-145, 2000.

BRAGA, J. C. S. A temporalidade da riqueza. 1985. 409f. Tese (Doutorado)Instituto de Economia da Universidade Estadual de Campinas, Campinas, Campinas, 1985.

BRAGA, J. C. S. (1992). A financeirização da riqueza: a macroestrutura financeira e a nova dinâmica dos capitalismos centrais. São Paulo, nov. 1992. (Texto para Discussão, n. 5).

BRAGA, J. C. S. A financeirização da riqueza. Economia e Sociedade, Campinas, n. 2, p. 25-27, 1993.

BRAGA, J. C. S. Financeirização global: o padrão sistêmico da riqueza do capitalismo. In: FIORI, J. L.; TAVARES, M. C. (Ed.). Poder e dinheiro: uma economia política da globalização. São Paulo: Vozes, 1997. p. 195-242.

BRAGA, J. C. S. Temporalidade da riqueza: teoria da dinâmica e financeirização do capitalismo. Campinas: IE/Unicamp, 2000.

BRAGA, J. C. S. Crise sistêmica da financeirização e a incerteza das mudanças. Estudos Avançados, v. 23, n. 65, p. 89-102, 2009.

BRAGA, J. C. S. Qual conceito de financeirização compreende o capitalismo contemporâneo? In: BARROSO, A. S.; SOUZA, R. (Eds.). A grande crise capitalista 2007-2013: gênese, conexões e tendências. São Paulo, SP: Ed. Anita Garibaldi, 2013.

BRAGA, J. C. S.; CINTRA, M. A. M. Finanças dolarizadas e capital financeiro: exasperação sob comando americano. In: FIORI, J. L. (Ed.). Poder americano. São Paulo: Vozes, 2004.

BRUNO, V. G., BÜYÜKŞAHIN, B.; ROBE, M. A. The financialization of food? American Journal of Agricultural Economics, p. 243-264, 2017.

BULLIO, O. Bancos, "shadow banks" e moeda endógena: desafios à política monetária do Federal Reserve no século XXI. 2015. 183f. Tese (Doutorado)- 
Instituto de Economia da Universidade Estadual de Campinas, Unicamp, Campinas, 2015.

CARNEIRO, R. L. The transition from quantity to quality: a neglected causal mechanism in accounting for social evolution. Proceedings of the National Academy of Sciences, v. 97, n. 23, p. 12926-12931, 2000.

CHENG, I. H.; XIONG, W. Financialization of commodity markets. Annual Review of Financial Economics, v. 6, n. 1, p. 419-441, 2014.

CHESNAIS, F. O capital portador de juros: acumulação, internacionalização, efeitos econômicos e políticos. In: CHESNAIS, F. (Ed.). A finança mundializada: raízes sociais e políticas, consequências. São Paulo: Boitempo. 2005. p. 35-67.

CINTRA, M. A. M.; CAGNIN, R. F. Evolução da estrutura e da dinâmica das finanças norte-americanas. Revista Econômica, v. 9, n. 2, p. 296-338, 2007.

CINTRA, M. A. M.; FARHI, M. A crise financeira e o global shadow banking system. Novos Estudos Cebrap, n. 82, p. 35-55, 2008.

COUTINHO, L.; BELLUZZO, L. G. Financeirização da riqueza, inflação de ativos e decisões de gasto em economias abertas. Economia e Sociedade, Campinas, v. 7, n. 2, p.137-150, 1998.

CREDIT SUISSE RESEARCH INSTITUTE. Global wealth report 2016. Zürich, Switzerland: Credit Suisse AG., 2016. Available: http://www.goo.gl/tVHQeT.

CROTTY, J. R. Owner-manager conflict and financial theories of investment instability: a critical assessment of Keynes, Tobin, and Minsky. Journal of Post Keynesian Economics, v. 12, n. 4, p. 519-542, 1990.

DE CONTI, B. M. Políticas cambial e monetária: os dilemas enfrentados por países emissores de moedas periféricas. 2011. 212f. Tese (Doutorado)-Instituto de Economia da Universidade Estadual de Campinas, Campinas, 2011.

DUMÉNIL, G.; LÉVY, D. The crisis of neoliberalism. Cambridge, Mass: Harvard University Press. 2011.

EATON, C., HABINEK, J., GOLDSTEIN, A., DIOUN, C., GODOY, D. G. S.; OSLEY-THOMAS, R. The financialization of US higher education. SocioEconomic Review, p. 507-535, 2016.

EPSTEIN, G. A. Introduction. In: EPSTEIN, G. A. (Ed.). Financialization and the World Economy. Cheltenham, UK: Edward Elgar, p. 3-16, 2005.

ERTURK, I.; FROUD, J.; JOHAL, S., LEAVER, A.; WILLIAMS, K. General introduction: Financialization, coupon pool and conjuncture. In: ERTURK, I. et. al. (Eds.). Financialisation at work. London, UK: Routledge. 2008. p. 1-44. 
FARHI, M. Derivativos financeiros: hedge, especulação e arbitragem. Economia e Sociedade, v. 8, n. 2, p. 93-114, 1999.

FOSTER, J. B. The financialization of capitalism. Monthly Review, v. 58, n.11, p. 1$12,2007$.

GLYN, A. Capitalism unleashed: finance globalization and welfare. Oxford; New York: Oxford University Press, 2006.

GUTTMANN, R. As mutações do capital financeiro. In: CHESNAIS, F. (Ed.). A mundialização financeira: gênese, custos e riscos. São Paulo: Xamã, 1998. p. 61-96. GUTTMANN, R. A primer on finance-led capitalism and its crisis. Introduction. Revue de La Régulation. Capitalisme, Institutions, Pouvoirs, n. 3-4, 2008.

GUTTMANN, R. Finance-led capitalism: shadow banking, re-regulation, and the future of global markets. New York: Palgrave Macmillan US, 2016.

HEIN, E. The macroeconomics of finance-dominated capitalism and its crisis. Cheltenham, Northampton, MA: Edward Elgar, 2012.

HELLEINER, E. States and the reemergence of global finance: from Bretton Woods to the 1990s. Ithaca, NY: Cornell University Press, 1994.

HELLEINER, E. Reinterpreting Bretton Woods: international development and the neglected origins of embedded liberalism. Development and Change, v. 37, n. 5, p. 943-967, 2006.

HELLEINER, E. Political determinants of international currencies: what future for the US dollar? Review of International Political Economy, v. 15, n. 3, p. 354-378, 2008.

HILFERDING, R. Finance capital. London: Routledge \& Kegan Paul, 1910 [1981].

HOBSBAWM, E. J. The age of extremes: the short twentieth century, 1914-1991. (repr). London: Abacus, 1995 [2011].

HOBSON, J. A. The evolution of modern capitalism. London: The Walter Scott Publising Co, Ltd., 1906.

KINDLEBERGER, C. Manias, panics, and crashes: a history of financial crises. Basingstoke, UK: Palgrave Macmillan, 1989 [2011].

KREGEL, J. Margins of safety and weight of the argument in generating financial fragility. Journal of Economic Issues, v. 31, n. 2, p. 543-548, 1997.

KREGEL, J. The natural instability of financial markets. Annandale-on-Hudson, NY: Levy Economics Institute, 2007. Reinterpreting Bretton Woods. (Working Paper, n. 523). 
KRIPPNER, G. R. What is financialization? Los Angeles, LA: University of California, 2004.

KRIPPNER, G. R. The financialization of the American economy. Socio-Economic Review, v. 3, n. 2, p. 173-208, 2005.

LAKE, R. W. The financialization of urban policy in the age of Obama. Journal of Urban Affairs, v. 37, n. 1, p. 75-78, 2015.

LAPAVITSAS, C. Theorizing financialization. Work, Employment \& Society, v. 25, n. 4, p. 611-626, 2011.

LENIN, V. I. Imperialism: the highest stage of capitalism. New York, NY: International, 1917 [1979].

LUND, S.; DARUVALA, T.; DOBBS, R.; HÄRLE, P.; KWEK, J. H.; FALCÓN, R. Financial globalization: retreat or reset? 2013. (Global Capital Markets 2013). Disponível em: https://goo.gl/QDqFMG.

MAGDOFF, H. Problems of United States capitalism. In: MILIBAND, R.; SAVILLE, J. (Ed.). Socialist register. London: Merlin, 1965.

MAGDOFF, F.; FOSTER, J. B. Stagnation and financialization: the nature of the contradiction. Monthly Review, v. 66, n. 1, p. 1-24, 2014.

MARX, K. Capital, v. 1. London: Penguin Books. 1867 [1976].

MARX, K. Capital, v. 3. London: Penguin Books. 1894 [1991].

MATTHEWS, N. A detailed analysis of the Fed's crisis response. In: WRAY, R. (Ed.). Reforming the fed's policy response in the era of shadow banking. New York: Levy Economics Institute and Ford Foundation, 2015.

METRI, M. O poder financeiro dos Estados Unidos no padrão monetário dólarflexível. In: ENCONTRO NACIONAL DE ECONOMIA POLÍTICA, 9, Uberlândia, MG, Brazil, 2004.

MINSKY, H. P. Stabilizing an unstable economy. New Haven: Yale University Press, 1986.

MINSKY, H. P. John Maynard Keynes. New York: Columbia University Press, 1975.

MONTGOMERIE, J. The pursuit of (past) happiness? Middle-class indebtedness and American financialisation. New Political Economy, v. 14, n. 1, p. 1-24, 2009.

OLIVEIRA, G. C. Financeirização da riqueza e dinâmica econômica. Ensaios FEE, Porto Alegre, v. 30, n. 2, p. 727-754, 2009. 
PALLEY, T. I. Financialization: the economics of finance capital domination. London: Palgrave Macmillan UK, 2013.

PALLUDETO, A. W. A. Os derivativos como capital fictício: uma interpretação marxista. 2016. 152 f. Tese (Doutorado)-Instituto de Economia da Universidade Estadual de Campinas, Campinas. 2016.

PALLUDETO, A. W. A.; ROSSI, P. O capital fictício: reinterpretação de uma categoria controversa. In: ENCONTRO NACIONAL DE ECONOMIA POLÍTICA, 21, São Bernardo do Campo, Brasil. 2016. Disponível em: https://goo.gl/Ugfg3m.

PERELMAN, M. The phenomenology of constant capital and fictitious capital. Review of Radical Political Economics, v. 22, n. 2-3, p. 66-91, 1990.

PHILLIPS, K. Boiling point: republicans, democrats, and the decline of the middleclass prosperity. New York: Random House, 1993.

PHILLIPS, K. Arrogant capital: Washington, Wall Street, and the frustration of American politics. New York, NY: Little, Brown and Co, 1994.

PIKETTY, T. Capital in the twenty-first century. Trad. A. Goldhammer. Cambridge Massachusetts: The Belknap Press of Harvard University Press, 2014.

PLIHON, D. As grandes empresas fragilizadas pela finança. In: CHESNAIS, F. (Ed.). A finança mundializada: raízes sociais e políticas, configuração, consequências. São Paulo: Boitempo, 2005.

POLLIN, R. Resurrection of the rentier. New Left Review, v. 46, p. 140-153, 2007.

PRATES, D. M. As assimetrias do sistema monetário e financeiro internacional. Revista de Economia Contemporânea, v. 9, n. 2, p. 263-288, 2005.

ROBERTS, M. Thomas Piketty and the Search for r. Historical Materialism, v. 23, n. 1, p. 86-105, 2015.

ROWTHORN, R. A note on Piketty's capital in the twenty-first century. Cambridge Journal of Economics, v. 38, n. 5, p. 1275-1284, 2014.

RUESGA, S. M. La financiarización de las relaciones laborales/labour relations financialization. Cuadernos de Relaciones Laborales, v. 30, n. 2, p. 409-429, 2012.

SAWYER, M. Confronting financialisation. In: ARESTIS, P.; SAWYER, M. (Ed.). Financial liberalisation. Cham: Springer International Publishing, 2016. p. 43-85.

SERFATI, C. Financial dimensions of transnational corporations, global value chain and technological innovation. Journal of Innovation Economics, v. 2, n. 2, p. 35-61, 2008. 
SINCLAIR, S. Financial inclusion and social financialisation: Britain in a European context. International Journal of Sociology and Social Policy, v. 33, n. 11-12, p. 658-676, 2013.

STOCKHAMMER, E. Some stylized facts on the finance-dominated accumulation regime. Competition \& Change, v. 12, n. 2, p. 184-202, 2008.

SWEEZY, P. M.; MAGDOFF H. The dynamics of U.S. capitalism: corporate structure, inflation, credit, gold, and the dollar. New York, NY: Monthly Review, 1972.

TAVARES, M. C. A retomada da economia norte-americana. In: FIORI, J. L.; TAVARES, M. C. (Ed.). Poder e dinheiro: uma economia política da globalização. São Paulo: Vozes, 1997.

TOPOROWSKI, J. Neologism as theoretical innovation in economics: the case of “financialisation.” In: O’SULliVAN, P., ALLINGTON, N. F. B.; ESPOSITO, M. (Ed.). The philosophy, politics and economics of finance in the 21st century: from hubris to disgrace. New York, NY: Routledge. 2015. p. 254-266.

VAN DER ZWAN, N. Making sense of financialization. Socio-Economic Review, v. 12, n. 1, p. 99-129, 2014.

VAN TREECK, T. The political economy debate on "financialization" - a macroeconomic perspective. Review of International Political Economy, v. 16, n. 5 , p. 907-944, 2009.

VEBLEN, T. The theory of business enterprise. C. Scribner's Sons, 1904.

WORLD FEDERATION OF EXCHANGES. Statistics definitions and examples. London: World Federation of Exchanges, 2013. 